\title{
Manajemen Digitalisasi Kurikulum di SMP Islam Cendekia Cianjur
}

Fitri Meliani', Dindin Alawi ${ }^{2}$, Muhammad Yamin $^{3}$, Muhibbin Syah ${ }^{4}$, Muhammad Erihadiana $^{5}$

1,2,3,4,5 Universitas Islam Negeri Sunan Gunung Djati Bandung, Indonesia

E-mail: fithinker1453@gmail.com, dindin alawi@cendekia.sch.id, muhammad yamin@gmail.com, muhibbinsyah@yahoo.com erihadiana@uinsgd.ac.id

\begin{tabular}{l}
\hline Article Info \\
\hline Article Histo \\
Received: 2021 \\
Revised: 2021-11 \\
Published: 2021 \\
\\
\\
Keywords: \\
Management; \\
Digitization; \\
Curriculum; \\
School; \\
Digital.
\end{tabular}

Sejarah Artikel

Diterima: 2021-10-09

Direvisi: 2021-11-02

Dipublikasi: 2021-11-23

Kata kunci:

Manajemen;

Digitalisasi;

Kurikulum;

Sekolah;

Digital.

\begin{abstract}
SMP Islam Cendekia Cianjur, one of modern pesantren (boarding school) in Cianjur, transformed their curriculum into digitization, because of the urgency of Distance Learning in pandemi. This research is a qualitative research. The purpose of this research is to describe the planning, implementation, evaluation, and results of digitalization curriculum, and to find the factors that encourage and hinder the success of curriculum digitization in SMP Islam Cendekia Cianjur. The research data was obtained from interviews using SWOT method to Head of the Foundation, the Principal, the Head of Boarding School, and the Deputy Principal of Curriculum, and IT Employees. Interviews with open ended questions were conducted with 5 teachers, and 5 students. The results of the study explain that in the implementation of curriculum digitization, teachers and students still need a lot of guidance to use the Information Technology platform during the learning process, so regular HR training is needed. Supporting factors for curriculum digitization, namely the openness of each personnel to change, joint commitment from the school community, facilities and infrastructure owned by the school, and inhibiting factors, namely an unstable internet network, lack of institutional ability to protect students when using the internet, and differences in resource speed. humans in adjustment to technological advances.
\end{abstract}
Abstrak
SMP Islam Cendekia Cianjur yaitu berbasis pesantren modern (boarding school) melakukan transformasi berupa digitalisasi kurikulum sekolah, karena urgensi Pembelajaran Jarak Jauh saat pandemi. Penelitian ini adalah penelitian kualitatif. Tujuan penelitan ini adalah untuk menjelaskan perencanaan, pelaksanaan, evaluasi, dan hasil digitalisasi kurikulum, serta faktor-faktor yang mendorong dan menghambat keberhasilan digitalisasi kurikulum di SMP Islam Cendekia Cianjur. Data penelitan didapatkan dari wawancara metode SWOT pada Ketua Yayasan, Kepala Sekolah, Kepala Boarding, dan Wakil Kepala Sekolah Bagian Kurikulum, dan Pegawai IT. Wawancara dengan open ended question dilakukan pada 5 orang guru, dan 5 orang murid. Hasil penelitian menjelaskan dalam pelaksanaan digitalisasi kurikulum, para guru dan murid masih butuh banyak bimbingan untuk menggunakan platform Teknologi Informasi selama proses pembelajaran, sehingga dibutuhkan pelatihan SDM secara berkala. Faktor pendukung digitalisasi kurikulum, yaitu keterbukaan setiap personil terhadap perubahan, komitmen bersama dari civitas sekolah, sarana dan prasarana yang dimiliki sekolah, dan faktor penghambat yaitu jaringan internet yang kurang stabil, kurangnya kemampuan lembaga dalam memproteksi siswa saat penggunaan internet, serta perbedaan kecepatan sumber daya manusia dalam penyesuaian dengan kemajuan teknologi.

\section{PENDAHULUAN}

Pandemi Covid-19 yang melanda sejak awal tahun 2020 memberikan dampak pada berbagai sektor kehidupan. Pemerintah dan masyarakat dituntut untuk melakukan adaptasi dengan datanganya pandemi tersebut sebagai upaya bertahan. Salah satu sektor yang terdampak yaitu pendidikan. Penutupan sementara lembaga pendidikan sebagai upaya menahan penyebaran pendemi Covid-19 di seluruh dunia berdampak pada jutaan pelajar, termasuk di
Indonesia, berdasarkan hal di atas, maka lembaga pendidikan perlu mempersiapkan kurikulum, merancang model, metode, strategi, media, dan evaluasi pembelajaran yang tepat di masa pandemi Covd-19. Pendidikan pesantren di Indonesia juga terkena dampaknya, dengan adanya kebijakan Pemerintah untuk meliburkan seluruh lembaga pendidikan sebagai upaya mencegah meluasnya penularan virus Covid-19. Menurut UNICEF sebagaimana dikutip (Nasser, 2021) mengemukakan bahwa kehadiran 
pandemi Covid-19 dapat dikatakan benar-benar menggeser tatanan pembelajaran yang telah diterapkan sbeelumnya. Salah satu bentuk adaptasi tersebut yaitu perubahan sistem belajar-mengajar yang semula tatap muka menjadi pembelajaran daring.

Salah satu lembaga pendidikan yang terdampak dalam pengelolaannya selama pandemi adalah pesantren dan boarding school. Menurut (Hasbi, 2021) bahwa Pesantren ialah sebuah bangku pendidikan dimana menonjolkan sisi pendidikan agama dalam keseharian. Pesantren memiliki kekhasan dan karakteristik tersendiri pada sistem pendidikan yang digunakan. Pada situasi Covid-19, ada usahausaha adaptasi yang dilakukan oleh pesantren dengan mengubah sistem pengelolaan atau manajemen pondok pesantren. Seiring perkembangan waktu, pengelolaan pondok pesantren dituntut dinamis dan mengikuti dinamika sosial yang terjadi dalam masyarakat secara global. Pengelolaan ini memiliki tujuan untuk memantau proses berjalannya pesantren dengan harapan dapat mengembangkan dan memajukan sebuah lembaga pondok pesantren. Menurut (Arifudin, 2021) bahwa proses pembelajaran daring ini melibatkan berbagai platform digital dan aplikasi penunjang pembelajaran seperti video conference berupa zoom meeting, google meet, webex ataupun media pembelajaran lain seperti google clasroom, kahoot, quizizz, dan berbagai platform lainnya yang mendukung pembelajaran.

Penggunaan teknologi informasi di masa pandemi bertujuan untuk mendorong penyelenggaraan pembelajaran yang efektif seperti yang tercantum di dalam isi Peraturan Menteri Pendidikan dan Kebudayaan No. 65 Tahun 2013 tentang pemanfaatan teknologi informasi untuk meningkatkan efisiensi dan efektivitas pembelajaran. Menurut (Smaldino, 2014) mengungkapkan bahwa teknologi dan media yang disesuaikan dan dirancang secara khusus bisa memberi kontribusi bagi pengajaran yang efektif dari seluruh siswa dan bisa membantu mereka meraih potensi tertinggi mereka, dengan adanya media pembelajaran berbasis internet supaya siswa dapat memperoleh pengalaman belajar yang maksimal melalui proses pembelajaran yang terstruktur. Hal tersebut sesuai dengan yang diungkapkan (Machali, 2015) bahwa pendidikan merupakan usaha sadar dan terencana mewujudkan suasana belajar dan proses pembelajaran agar siswa secara aktif mengembangkan potensi dirinya.
Pada masa pandemi ini, SMP Islam Cendekia Cianjur yang berbasis pesantren modern (boarding school) sebagai tempat berkumpul para santri dari berbagai daerah juga dituntut untuk beradaptasi dengan adanya pandemi. Kebijakan-kebijakan terus dirundingkan sebagai bentuk pertahanan di masa pandemi ini. SICC (SMP Islam Cendekia Cianjur) adalah sebuah Sekolah Menegah Islam yang memiliki visi misi luhur berbasis Alquran dan Sunnah dalam mencetak para penerus bangsa. Sejak 2018, SICC memiliki wacana untuk menjadi sekolah percontohan dengan fasilitas Digital School, namun baru dapat diwujudkan saat adanya pandemi Covid-19, karena didorong oleh tuntutan PJJ (pembelajaran jarak jauh), tantangan era revolusi industri 4.0 menuju digitalisasi pembelajaran dan gerakan revolusi hijau di kalangan pesantren (paperless). Untuk menjawab tantangan-tantangan tersebut, sekolah mengupayakan berbagai macam hal. Mulai dari pelatihan penggunaan platform berbasis digital bagi para guru dan tenaga pendukung dari lembaga eksternal maupun internal, agar mereka dapat menggunakan platform digital premium seperti Canva (untuk pembuatan media pembelajaran), Quizziz dan Bookwidgets untuk evaluasi pembelajaran. Baik siswa maupun guru dituntut beradaptasi dengan cepat agar proses pembelajaran tetap dapat berjalan dengan optimal. Namun tidak semua siswa dan guru dapat dengan cepat memahami dan mengakses sarana teknologi yang telah disediakan oleh sekolah. Berdasarkan pemaparan masalah di atas, maka penulis menaruh ketertarikan untuk meneliti lebih dalam terkait Manajemen Digitalisasi Kurikulum di SMP Islam Cendekia Cianjur.

1. SMP Islam Cendekia Cianjur

SMP Islam Cendekia Cianjur (SICC) adalah sebuah Sekolah Menengah Pertama yang terletak di Jalan Pramuka, Kota Cianjur. Kepala Sekolah SMP Islam Cendekia Cianjur sekarang adalah Dera Nugraha, S.Pd.I., M.I.Kom. Status Sekolah ini adalah Sekolah Standar Nasional. Sejarah singkat SICC, dengan melekat nama cendekia menyirat harapan dan cita-cita bahawa ouput dari proses pendidikan yang diselenggarakan kelak memiliki kopentensi dalam bidang sains dan tekonologi sebagai penguatan pendidikan karakter yang berbasis agama Islam. SMP Islam Cendekia Cianjur menggunakan Kurikulum Umum dari Departemen Pendidikan Nasional. Selain itu diberikan program 
khusus yang bersifat keagamaan, antara lain:Tahfidz Al-Qur'an, Bahasa Arab, aqidah Akhlak, Bahasa Inggris, dan Sains. Dilengkai fasilitas gedung perpustakaan, laboratorium computer, laboratorium bahasa, sistem computer, laboratorium IPA, masjid, lapangan olah raga, balai pengobatan uks, dokter jaga, music studio, foto \& video studio, kantin, foodcourt, SICC mart. Adapun ekstrakurikuler yang diselenggarakan di SICC adalah fun math, sains, futsal, basket, IT Club, Marching Band, silat, karate, pramuka, PMR, Paskibra, English $C l u b$, musik, fotograpi, dan tenis meja.

SICC memiliki jargon Digital School, dan sejak 2018 dan memiliki visi dan misi menjadi sekolah percontohan dalam digitalisasi kurikulum, SICC sudah tiga tahun melakukan program pertukaran guru dan pelajar dengan sebuah sekolah digital di Australia. SICC menjadi percontohan sekolah berbasis digital di kota Cianjur, dan beberapa kali bekerja sama dengan pemerintah setempat untuk membuat pelatihan online bagi para akademisi dan masyarakat umum dengan mengangkat tema "Penggunaan platform Teknologi Informasi (TI) di masa Pandemi”.

\section{Digitalisasi Kurikulum}

Menurut Wawan yang dikutip (Munir, 2008) bahwa teknologi informasi adalah suatu teknologi yang digunakan untuk mengolab data, tennasuk memproses, mendapatkan, menyusun, menyimpan, memanipulasi data sebagai cara untuk menghasilkan informnasi yang berkualitas, yaitu infonnasi yang relevan, akurat, dan tepat waktu yang digunakan untuk keperluan pribadi, bisnis, dan pemerintaban yang merupakan aspek strategis untuk pengam-bilan keputusan. Sementara Martin, sebagaimana dikutip oleh (Kadir, 2003) menjelaskan teknologi informasi tidak banya terbatas pada tekuologi komputer (perangkat keras hardware dan perangkat lunak/ software) yang digunakan untuk memproses dan menyimpan infonnasi melainkanjuga mencakup teknologi komunikasi untuk mengirimkan informasi, dengan demikian, pengertian evaluasi pemanfaatan teknologi informasi (TI) di pesantren yang dirnaksud dalam penelitian ini adalab suatu proses yang digunakan untuk menilai bagaimana penggunaan berbagai sumber sarana dan prasarana (hardware, software dan useware), sistem, dan metode untuk memperoleh, mengolah, menyimpan, dan mengirim data secara bermakna di pondok pesantren, teknologi Informasi (TI) digolongkan menjadi tiga bagian (Munir, 2008) yaitu:

a) Perangkat Keras, terdiri dari unit pemrosesan pusat atau yang lebih dikenal dengan nama Central Processing Unit (CPU), piranti masukan (input device), piranti keluaran (output device), memori utama (main memory) dan piranti penyimpan sekunder.

b) Perangkat Lunak, dikelompokan menjadi program aplikasi (aplication program) dan program sistem (system program),

c) Brainware adalah pengguna komputer yang terdiri atas tiga tingkatan yaitu operator, programmer dan analis.

Menurut Puranto sebagaimana dikutip (Arifudin, 2019) mengemukakan bahwa pendidikan berbasis teknologi informasi (TI) dapat terselenggara dengan baik apabila persyaratan yang terkait dengan ketersediaan teknologi, penguasaan pengetahuan, dan keterampilan untuk mengembangkan konten dukungan kebijakan dan kesiapan masyarakat dipenuhi, menurut (Irwansyah, 2021) mengemukakan bahwa ketersediaan infrastruktur menjadi syarat pertama karena dengan tersedianya alat teknologi, maka adopsi dapat terjadi. Adopsi terjadi melalui proses penguasaan pengetahuan dan keterampilan mengadapatasi e-Iearning dalam proses pembelajaran berbasis TI serta melakukan pengembangan konten sehingga infrastruktur yang ada bermanfaat secara optimal. Selanjutnya perlu ketersediaan dukungan kebijakan dari pemerintah berupa kepedulian terhadap TI yang dituangkan dalam kebijakan rencana lima tahun. Bentuknya dapat melalui pengalokasian dana khusus oleh pemerintah pusat dan daerah. Syarat lain yaitu terciptanya kesiapan masyarakat. Pendidikan berbasis TI tidak akan terselenggara jika masyarakatnya belum siap atau belum terampil TI.

Berkaitan dengan tahapan penggunaan TI dalam proses pembelajaran, UNESCO sebagaimana dikutip (Mayasari, 2021) mengemukakan bahwa mengklasifikasi tahap penggunaan IT sehubungan dengan pembelajaran ke dalam empat tahap. Tahap pertama adalah tahap emerging. Institusi baru menyadari pentinguya TI untuk pembelajaran dan belum berupaya untuk menerapkannya. Tahapan berikutuya adalah tahap applying. 
Tahap ini satu langkah lebib maju di mana TI telah dijadikan objek untuk dipelajari (mata pelajaran). Pada tahap ketiga, yakni tahap integrating, TI telah diintegrasikan ke dalam kurilrulum (pembelajaran). Tahap keempat atau tahap transforming adalah tahap yang paling ideal di mana TI telah rnenjadi katalis bagi perubahan atau evolusi pendidikan. TI diaplikasikan secara penuh, baik untuk proses pembelajaran (instructional purpose) maupun untuk adrninistrasi (administrational purpose) pada penelitian ini di SMP Islam Cendekia Cianjur berada pada tahap applying.

\section{METODE PENELITIAN}

Penelitian ini menggunakan pendekatan kualitatif, tujuan dalam penelitian adalah untuk mendapatkan gambaran pelaksanaan Manajemen Digitalisasi Kurikulum di SMP Islam Cendekia Cianjur. Menurut (Rahayu, 2020) mengemukakan bahwa penelitian kualitatif merupakan penelitian yang mencari gambaran secara mendalam terkait sebuah fenomena yang terjadi, Satu-satunya unsur perlakuan yang diberikan dalam penelitian ini hanyalah penelitian itu sendiri yang dilakukan melalui wawancara, observasi pengedaran angket atau dokumentasi. Langkah-langkah penelitian ini meliputi: tahap persiapan, diagnostik, perencanaan, pelaksanaan, evaluasi, dan hasil.

1. Subjek Penelitian

Subjek penelitian ini adalah Ketua Yayasan, Kepala Sekolah, Kepala Boarding, dan Wakil Kepala Sekolah Bagian Kurikulum, Pegawai IT, 5 guru dan 5 siswa di SMP Islam Cendekia Cianjut.

2. Lokasi Penelitian

Penelitian ini dilaksanakan di SMP Islam Cendekia Cianjur.

3. Waktu Penelitian

Penelitian ini dilaksanakan pada semester ganjil tahun Pembelajaran 2021/2022, dengan waktu pelaksanaan selama dua bulan, yaitu bulan September-Oktober 2021.

4. Teknik Pengumpulan Data

Teknik pengumpulan data yang digunakan dalam penelitian adalah tes dan Oservasi.

a) Wawancara

Pengumpulan data dengan wawancara metode SWOT (strength/kekuatan, weakness/ kelemahan, opportunity/ peluang, treats/ hambatan) kepada Ketua Yayasan, Kepala Sekolah, Kepala Boarding school, dan Wakil Kepala Sekolah Bagian Kurikulum, Pegawai IT. Wawancara dengan list pertanyaan open-ended ditanyakan pada 5 guru, 5 siswa, dan 5 wali murid. Wawancara menurut (Bahri, 2021) mengemukakan bahwa teknik mengumpulkan informasi dengan cara mengkonfirmasi narasumber yang terkait dengan tema penelitian.

b) Observasi

Observasi digunakan untuk menjawab permasalahan yang diajukan dalam penelitian ini. Lembar observasi digunakan untuk mengamati kinerja guru dan aktivitas siswa saat pembelajaran dilaksanakan oleh pengamata (Observer). Menurut (Sugiyono, 2015) menjelaskan bahwa, observasi merupakan dasar dari semua ilmu pengetahuan. Teknik observasi yang digunakan dalam penelitian ini menggunakan Teknik "semi terstruktur" yang memberikan ruang gerak bagi peneliti untuk mengubah fokus dari satu kejadian ke kejadian lain seiring dengan munculnya kejadian-kejadian baru yang mungkin lebih memiliki daya tarik dan menjadi penyebab munculnya kejadian ke kejadian lain.

5. Alat Pengumpulan Data

Alat pengumpulan data yang digunakan dalam penelitian ini ada dua, yaitu lembar wawancara dan lembar panduan observasi.

a) Lembar wawancara

Lembar wawancara digunakan untuk menjaring persepsi para subyek penelitian.

b) Lembar Panduan Observasi

Instrumen ini dirancang peneliti untuk mengumpulkan data mengenai kinerja guru dan aktivitas belajar siswa selama penelitian.

6. Teknik Analisis Data

Penelitian ini dianalisis dengan menggunakan analisis data kualitatif. Analisis kualitatif, digunakan untuk menganalisis data hsil wawancara dan observasi yang menunjukkan proses yang memberikan pemaknaan secara kontekstual dan mendalam sesuai dengan permasalahan penelitian yaitu tentang digitalisasi kurikulum.

7. Prosedur Penelitian

Langkah-langkah penelitian disusun dan dikembangkan secara sistematis untuk mempermudah proses pelaksanaan penelitian, prosedur penelitian ini adalah:

a) Tahap Persiapan

Pada tahap persiapan, peneliti memilih masalah penelitian dengan melakukan 
studi kepustakaan yang berasal dari beberapa rujukan seperti buku, disertasi, jurnal dan lain-lain, selanjutnya melakukan studi ke lokasi penelitian sebagai pendahuluan, dengan melakukan diskusi dengan kepala sekolah dan wakil kepala sekolah bidang kurikulum untuk merumuskan permasalahan. Melalui serangkaian diskusi kelompok, kemudian memilih pendekatan yang akan digunakan yaitu pendekatan penelitian kualitatif metode deskriptif analitik serta menentukan lokasi dan subjek penelitian. Lokasi Penelitian yaitu SMP Islam Cendekia Cianjur. Sumber data didapatkan dari hasil pengumpulan data dari wawancara, observasi dan kuesioner. Penentuan dan penyusunan instrumen yang akan digunakan dalam kegiatan penelitian, dilakukan atas kerja sama kelompok dengan dilakukan analisis untuk menentukan validitas dan reliabilitas instrumen.

b) Tahap Pelaksanaan

Pada tahap pelaksanaan, penneliti secara langsung terlibat dalam proses pembelajaran di SMP Islam Cendekia Cianjur dengan melakukan observasi, wawancara dengan kepala sekolah dan wakil kepala sekolah bidang kurikulum serta penyebaran kuesioner kepada wakil kepala sekolah, pihak IT, guru, peserta didik dan perwakilan orangtua.

c) Tahap Pengolahan Data

Kegiatan yang dilaksanakan dalam tahap ini adalah Pengolahan dan penganalisisan data hasil penelitian berupa hasil wawancara, observasi dan kuesioner, kemudian penarikan kesimpulan dari hasil olah data dan analisis data penelitian.

d) Tahap Penyusunan Laporan

Penulisan laporan dalam bentuk tulisan disesuaikan dengan ketentuan penulisan karya tulis ilmiah.

\section{HASIL DAN PEMBAHASAN}

Berdasarkan wawancara dengan Kepala Yayasan, Kepala Sekolah, Kepala Boarding School, Wakil Kepala Sekolah Bagian Kurikulum dan pegawai IT SICC, didapatkan informasi bahwa:

1. Strengths (kekuatan) SICC, yaitu memiliki (1) guru-guru muda (25-34 tahun) yang memiliki kompetensi (jurusan yang linear dengan mata pelajaran yang diajarkan) sesuai dengan citacita dan harapan lembaga, (2) sekolah memiliki model pembelajaran digital yang berbeda dan unggul dibanding lembaga lain yang masih satu lingkungan dengan SICC dan dilengkapi dengan sarana-prasarana yang mendukung pembelajaran digital.

2. Weaknesses, yaitu kurangnya kemampuan lembaga dalam memproteksi siswa saat penggunaan internet, serta perbedaan kecepatan sumber daya manusia (terutama para guru dan pegawai kependidikan) dalam penyesuaian dengan penggunaan platform Teknologi Informasi baik dalam proses pembelajaran (instructional purpose) maupun adrninistrasi (administrational purpose).

3. Opportunities, sesuai dengan jargon Sekolah Digital yaitu, (1) SICC banyak mengembangkan keterampilan pendidik dan peserta didik di bidang TIK mengingat kebutuhan yang besar dalam menyambut era revolusi industri 4.0, misalnya menggelar pelatihan-pelatihan virtual mengenai penggunaan platform Teknologi Informasi baik untuk internal (siswa, guru, TU dan wali murid) maupun eksternal (sekolah lain dan masyarakat sekitar SICC), (2) membuat kegiatan-kegiatan yang menstimulasi kreativitas para guru dan siswa dalam menggunakan aplikasi teknologi seperti lomba konten dakwah dengan Canva, juga (3) meningkatkan kegiatan ekstrakurikuler IT club dengan membuat podcast tematik yang diisi oleh siswa sendiri dan diunggah di channel YouTube sekolah, sekaligus sebagai sosialisasi pada masyarakat luas.

4. Threat, yaitu ancaman yang dirasakan mulai bermunculan banyak lembaga pendidikan Islam yang serupa dengan SICC yaitu mengusung digital school.

Kepala Sekolah menerangkan bahwa pada dasarnya identifikasi sumber daya dan potensi yang dimiliki oleh SMP Islam Cendekia Cianjur yaitu dengan melihat sumber daya apa yang dimiliki baik dari segi fasilitas maupun pengajar, serta perbaikan pada aspek-aspek yang masih menjadi kelemahan lembaga. Identifikasi Sumber daya atau potensi yang dimiliki sudah mengikuti sistem analisis SWOT dimana kegiatan tersebut sudah dilakukan dengan menggunakan analisis yang tepat. Dengan menggunakan analisis SWOT lembaga dapat meminimalisir kelemahan dan ancaman. Selain dari analisis SWOT, SICC menggunakan analisis mentah lembaga dan beberapa keterangan dari guru mengenai bagaimana caranya para siswa bisa mendapatkan pembelajaran teknologi secara merata yang 
mendukung kemampuan mereka sesuai dengan ciri khas dan budaya pondok pesantren.

Pada awal masuk boarding school, sekolah mendata keberagaman siswa dari jenis kelamin, tingkat ekonomi, kemampuan akademis, dan sosio-emosional santri dalam beradaptasi. Guru boarding school memiliki tugas untuk memerhatikan para santri dan santriwatinya bila mereka butuh tempat untuk meminta pendapat, curhat atau materi pelajaran pagi-malam yang belum mereka pahami. Hal ini bertujuan untuk membimbing santri untuk hidup mandiri dan mampu mengikuti kegiatan di sekolah dengan baik. asrama ikhwan dan akhwat terpisah. Keberagaman tingkat ekonomi pada santri dikelompokkan menjadi dua, yaitu regular (menengah-keatas) dan beasiswa (dhuafa berprestasi). Pengelompokkan itu hanya bersifat data, dan berfungsi dalam proses bimbingan agar tidak terjadi ketimpangan sosial selama sekolah dan di asrama.

Pelaksanaan digitalisasi kurikulum harus memerhatikan keberagaman santri agar selalu memerhatikan segi kemampuan (akademik), latar belakang keluarga dan jenis kelamin. Hal tersebut dilaksanakan untuk memudahkan proses pembelajaran serta memudahkan para guru dalam memperlakukan para peserta didik dengan keberagaman yang ada dengan memerhatikan berbagai macam aspek. Hal tersebut sesuai dengan pendapat Lopez (2013), mengatakan bahwa pelaksanaan inovasi kurikulum harus berdasarkan kebutuhan pelajar masing-masing yang unik, seperti aspek-aspek berikut: 1) Ras dan etnis, 2) Gender siswa, 3) kemampuan siswa, 4) status ekonomi siswa, 5) Kemampuan bahasa Inggris dan Arab, dan 6) pendidikan inklusi bagi anak difable.

\section{Perencanaan}

Tahap perencanaan yang dilakukan oleh SMP Islam Cendekia Cianjur (SICC) dilakukan dengan identifikasi profil luluan yang disesuaikan dengan visi dan misi Yayasan Pribadi Kamila. Proses identifikasi profil lulusan menurut Salinan lampiran Peraturan Menteri Pendidikan dan Kebudayaan Nomor 20 Tahun 2016 dikatakan bahwa Standar Kompetensi Lulusan adalah kriteria mengenai kualifikasi kemampuan lulusan yang mencakup sikap, pengetahuan, dan keterampilan. Standar Kompetensi Lulusan pada jenjang SMP/MTs/SMPLB Paket B yang tertuang dalam Peraturan Kementerian Pendidikan dan Kebudayaan Nomor 20 Tahun 2016 mengenai Standar Kompetensi Lulusan dan dalam Identifikasi Profil Lulusan SICC sudah mencakup ketiga aspek yaitu dalam aspek sikap menjadikan siswa memiliki (1) Iman dan Taqwa, (2) Ilmu Pengetahuan dan (3) Teknologi hal tersebut menjadi standar capaian, SICC melakukan berbagai macam pertimbangan dalam menghadapi pendidikan di masa pandemi diawali dengan:

a) Pertama-tama Kepala sekolah mengadakan pertemuan dengan Kepala boarding school, Wakasek Bagian Kurikulum dan para guru untuk menyaring kebutuhan mengajar saat pandemi, rancangan anggaran dan membuat keputusan akan mengalihkan pembelajaran dengan menggunakan aplikasi teknologi informasi, yaitu dengan pembuatan LMS (learning management system) untuk mendukung proses pembelajaran dan administrasi sekolah,

b) Kedua, merencanakan penyuluhan dan pelatihan bagi seluruh anggota manajemen dan pengajar di SICC agar dapat menggunakan sarana dan prasarana digital di sekolah maupun selama pembelajaran di rumah.

c) Ketiga, bagian kurikulum dan IT sekolah melakukan rapat internal berkaitan dengan pembuatan tutorial penggunaan aplikasi teknologi informasi bagi seluruh guru dan murid, untuk memudahkan mereka dalam menggunakan aplikasi pembelajaran berupa LMS (learning management system) untuk guru dan siswa, dan website khusus pegawai TU untuk administrasi sekolah,

d) Terakhir, mengadakan pertemuan virtual dengan para wali murid untuk melakukan sosialisasi.

Proses yang dilakukan SICC sesuai dengan pendapat (Hamalik, 2010) mengemukakan bahwa dalam sebuah perencanaan kurikulum haruss melibatkan banyak pihak, antara lain kelompok guru mata pelajaran, kepala sekolah, pemerhati pendidikan, orang tua, stakeholder dan pihak-pihak lain yang terkait. Sedangkan pada level lebih tinggi yang menyangkut standar di dalam Pendidikan SICC melibatkan badan akreditasi serta kementerian agama biasanya meliputi standar proses sampai dengan standar pembiayaan SICC menyiapkan sebuah sistem dan mekanisme yang bertujuan agar suatu penambahan kurikulum dalam bentuk penambahan mata pelajaran dapat diterima dan disetujui oleh pihak-pihak terkait. 
Sebenarnya rencana digitalisasi kurikulum sudah direncanakan sejak tahun 2018 oleh sekolah, namun baru dapat direalisasi pada Maret 2019 saat ada tuntutan Pembelajaran Jarak Jauh. Selama pandemi, SMP Islam Cendekia Cianjur melakukan banyak perubahan, karena adanya tuntutan kebutuhan pembelajaran. Pada Maret-Juli 2020, SICC melakukan pembelajaran secara daring, dan siswa tinggal di rumah masingmasing. Pada Agustus 2020-Juli 2021, pembelajaran dilakukan secara hybrid, yairu sebulan tinggal di rumah, sebulan tinggal di boarding school. Namun sejak Agustus 2021, pembelajaran dilakukan secara tatap muka di boarding school sampai sekarang dengan menerapkan protokol kesehatan.

\section{Pelaksanaan}

Penyediaan sumber belajar yang digunakan dalam proses pembelajaran pada setiap mata pelajaran di SICC dibagi tiga, yaitu Buku Paket yang dapat dibeli di SICC Mart, Modul yang dibuat oleh guru setiap pertemuannya dan dapat diakses di LSM (Learning Management System), dan buku pelajaran yang bisa dipinjam di Gedung Perpustakaan SICC, Rohani dalam (Hanafiah, 2021) mengemukakan bahwa sumber belajar (Learning Resources) adalah segala macam sumber belajar yang ada di luar diri seseorang (peserta didik) dan yang memungkinkan (memudahkan) terjadinya proses belajar. Selain dari itu tersedia juga perpustakaan yang berguna untuk mencari sumbersumber lain yang dibutuhkan dalam pembelajaran. Selain dari itu sumber belajar yang tersedia disini berupa kitab-kitab yang dapat menunjang para peserta didik dan para guru dalam memperluas khazanah keilmuan. Teknologi juga menjadi sumber belajar yang digunakan dalam menunjang proses pembelajaran di kelas, pelaksanaan digitalisasi pembelajaran di setiap kelas adalah sebagai berikut:

a) Siswa mengambil laptop masing-masing di rung multimedia dan dibawa ke kelas,

b) Mengawali setiap pembelajaran dengan membaca ayat suci Al-Quran bersama guru,

c) Guru dan siswa menyalakan laptop dan membuka bahan ajar pembelajaran yang bisa diakses di LMS, berupa modul, video pembelajaran, dan LKPD (yang dibuat di Canva atau Powtoon), d) Siswa mengumpulkan tugas lewat LMS, dan

e) Guru dan siswa mengisi absen di LMS.

Penambahan kegiatan untuk meningkatkan motivasi belajar siswa yang digelar oleh sekolah adalah:

a) New Insight SICC: program holaqoh siswa, untuk memfalisitasi holaqoh siswa secara jarak jauh.

b) Pelatihan AKM (ujian nasional) dengan computer based,

c) Project based learning: siswa melakukan berbagai macam praktikum untuk memfasilitasi pembelajaran jarak jauh,

d) Karya ilmiah dakwah: meningkatkan keterampilan menulis, minat dan kepercayaan diri siswa dengan menggunakan platform Teknologi Informasi yang diarahkan sekolah.

Tabel 1. Daftar Mata Pelajaran dan Media Pembelajaran dalam Digitalisasi Kurikulum

\begin{tabular}{|c|c|c|c|c|}
\hline No & $\begin{array}{l}\text { Mata } \\
\text { Pelajaran }\end{array}$ & Bahan Ajar & Metode & Media \\
\hline \multicolumn{5}{|c|}{ Kurikulum Kementerian Agama } \\
\hline 1 & $\begin{array}{l}\text { Pend. } \\
\text { Agama } \\
\text { Islam }\end{array}$ & $\begin{array}{l}\text { Buku dan } \\
\text { Modul }\end{array}$ & $\begin{array}{l}\text { Ceramah, } \\
\text { Tanya } \\
\text { Jawab }\end{array}$ & $\begin{array}{l}\text { LMS, Gadget, } \\
\text { LCD Projector }\end{array}$ \\
\hline 2 & Tauhid & $\begin{array}{l}\text { Buku dan } \\
\text { Modul }\end{array}$ & $\begin{array}{l}\text { Ceramah, } \\
\text { Tanya } \\
\text { Jawab }\end{array}$ & $\begin{array}{l}\text { LMS, Gadget, } \\
\text { LCD Projector }\end{array}$ \\
\hline 3 & $\begin{array}{l}\text { Baca Tulis } \\
\text { AL-Qur'an }\end{array}$ & $\begin{array}{l}\text { AL-Qur'an, } \\
\text { Buku dan } \\
\text { Modul }\end{array}$ & Praktek & $\begin{array}{l}\text { LMS, Gadget, } \\
\text { LCD Projector }\end{array}$ \\
\hline 4 & Fiqih & $\begin{array}{l}\text { Buku dan } \\
\text { Modul }\end{array}$ & $\begin{array}{l}\text { Ceramah, } \\
\text { Tanya } \\
\text { Jawab }\end{array}$ & $\begin{array}{l}\text { LMS, Gadget, } \\
\text { LCD Projector }\end{array}$ \\
\hline 5 & Tajwid & $\begin{array}{l}\text { Buku dan } \\
\text { Modul }\end{array}$ & $\begin{array}{l}\text { Ceramah, } \\
\text { Tanya } \\
\text { Jawab }\end{array}$ & $\begin{array}{l}\text { LMS, Gadget, } \\
\text { LCD Projector }\end{array}$ \\
\hline 6 & $\begin{array}{l}\text { Bahasa } \\
\text { Arab }\end{array}$ & $\begin{array}{l}\text { Buku dan } \\
\text { Modul }\end{array}$ & $\begin{array}{l}\text { Ceramah, } \\
\text { Tanya } \\
\text { Jawab, } \\
\text { Praktek }\end{array}$ & $\begin{array}{l}\text { LMS, Gadget, } \\
\text { LCD Projector }\end{array}$ \\
\hline \multicolumn{5}{|c|}{ Kurikulum Nasional } \\
\hline 7 & PPkN & $\begin{array}{l}\text { Buku dan } \\
\text { Modul }\end{array}$ & $\begin{array}{l}\text { Ceramah, } \\
\text { Tanya } \\
\text { Jawab }\end{array}$ & $\begin{array}{l}\text { LMS, Gadget, } \\
\text { LCD Projector }\end{array}$ \\
\hline 8 & $\begin{array}{l}\text { Bhs. } \\
\text { Indonesia }\end{array}$ & $\begin{array}{l}\text { Buku dan } \\
\text { Modul }\end{array}$ & $\begin{array}{l}\text { Ceramah, } \\
\text { Tanya } \\
\text { Jawab }\end{array}$ & $\begin{array}{l}\text { LMS, Gadget, } \\
\text { LCD Projector }\end{array}$ \\
\hline 9 & $\begin{array}{l}\text { Bhs. } \\
\text { Inggris }\end{array}$ & $\begin{array}{l}\text { Buku dan } \\
\text { Modul }\end{array}$ & $\begin{array}{l}\text { Ceramah, } \\
\text { Tanya } \\
\text { Jawab }\end{array}$ & $\begin{array}{l}\text { LMS, Gadget, } \\
\text { LCD Projector }\end{array}$ \\
\hline 10 & $\begin{array}{l}\text { Matematik } \\
\text { a }\end{array}$ & $\begin{array}{l}\text { Buku dan } \\
\text { Modul }\end{array}$ & $\begin{array}{l}\text { Ceramah, } \\
\text { Tanya } \\
\text { Jawab }\end{array}$ & $\begin{array}{l}\text { LMS, Gadget, } \\
\text { LCD Projector }\end{array}$ \\
\hline 11 & Biologi & $\begin{array}{l}\text { Buku dan } \\
\text { Modul }\end{array}$ & $\begin{array}{l}\text { Ceramah, } \\
\text { Tanya } \\
\text { Jawab, } \\
\text { Praktek }\end{array}$ & $\begin{array}{l}\text { LMS, Gadget, } \\
\text { LCD Projector, } \\
\text { Lab }\end{array}$ \\
\hline 12 & Fisika & $\begin{array}{l}\text { Buku dan } \\
\text { Modul }\end{array}$ & $\begin{array}{l}\text { Ceramah, } \\
\text { Tanya } \\
\text { Jawab }\end{array}$ & $\begin{array}{l}\text { LMS, Gadget, } \\
\text { LCD Projector, } \\
\text { Lab }\end{array}$ \\
\hline 13 & IPS & $\begin{array}{l}\text { Buku dan } \\
\text { Modul }\end{array}$ & $\begin{array}{l}\text { Ceramah, } \\
\text { Tanya }\end{array}$ & $\begin{array}{l}\text { LMS, Gadget, } \\
\text { LCD Projector }\end{array}$ \\
\hline
\end{tabular}




\begin{tabular}{|c|c|c|c|c|}
\hline & & & Jawab & \\
\hline 14 & TIK & $\begin{array}{l}\text { Buku dan } \\
\text { Modul }\end{array}$ & $\begin{array}{l}\text { Praktek, } \\
\text { Tanya } \\
\text { Jawab }\end{array}$ & $\begin{array}{l}\text { LMS, Gadget, } \\
\text { LCD Projector, } \\
\text { Lab }\end{array}$ \\
\hline 15 & Olahraga & $\begin{array}{l}\text { Buku dan } \\
\text { Modul }\end{array}$ & Ceramah & $\begin{array}{l}\text { Gadget, } \\
\text { Lapangan, Alat } \\
\text { Olahraga }\end{array}$ \\
\hline 16 & BK & $\begin{array}{l}\text { Buku dan } \\
\text { Modul }\end{array}$ & $\begin{array}{l}\text { Ceramah, } \\
\text { Tanya } \\
\text { Jawab }\end{array}$ & $\begin{array}{l}\text { LMS, Gadget, } \\
\text { LCD Projector, }\end{array}$ \\
\hline 17 & $\begin{array}{l}\text { Seni } \\
\text { Budaya \& } \\
\text { Keterampil } \\
\text { an } \\
\end{array}$ & $\begin{array}{l}\text { Buku dan } \\
\text { Modul }\end{array}$ & Praktek & $\begin{array}{l}\text { LMS, Gadget, } \\
\text { LCD Projector, } \\
\text { Alat seni }\end{array}$ \\
\hline \multicolumn{5}{|c|}{ Kurikulum Boarding School } \\
\hline 18 & Safinah & $\begin{array}{l}\text { Buku dan } \\
\text { Modul }\end{array}$ & $\begin{array}{l}\text { Praktek, } \\
\text { Tanya } \\
\text { Jawab }\end{array}$ & $\begin{array}{l}\text { LMS, Gadget, } \\
\text { Tradisional }\end{array}$ \\
\hline 19 & Holaqoh & AL-Qur'an & Dzikir & $\begin{array}{l}\text { LMS, Gadget, } \\
\text { Tradisional }\end{array}$ \\
\hline
\end{tabular}

Respon santri terhadap digitalisasi administrasi kurikulum sangat beragam berdasarkan wawancara. Ada yang sangat menyambut baik digitalisasi ini karena memudahkan pembelajaran, ada juga yang mengeluhkan sulit karena santri jadi banyak tugas, ada yang senang karena boleh membawa laptop ke sekolah. Para santri memiliki pendapat yang sama dalam menanggapi penggunaan aplikasi teknologi informasi, yaitu sering lupauntuk absen karena tidak lagi dalam bentuk kertas yang tinggal tanda tangan, tapi harus mengakses LMS sebagai baru kehadirannya terdata, dan merasa repot karena harus mengerjakan PR di halaman LMS, bukan di buku. Berkurangnya interaksi dengan para guru selama pandemi dan digitalisasi kurikulum ini juga mempengaruhi motivasi santri dalam belajar.

\section{Evaluasi}

Dalam proses pembelajaran, menurut (Rezky, 2020) banyak problematika yang dihadapi oleh guru sebagai pendidik yang terbagi dalam beberapa indikator di antaranya: 1) proses penyampaian materi pembelajaran, 2) proses interaksi dengan siswa dalam proses pembelajaran, 3) kualitas pemberdayaan sarana dan elemen dalam pembelajaran, 4) mengelola bahan ajar untuk disampaikan dalam proses pembelajaran, dan 5) penyusunan perangkat Kurikulum yang sesuai dengan kondisi saat ini, setelah melakukan pembelajaran bergantian tatap muka dan karantina pesantren sejak Maret 2020-Juli 2021, pihak sekolah dan orang tua siswa melakukan evaluasi dan diambil keputusan bahwa pembelajaran tahun ajaran baru Agustus 2021, pembelajaran akan full dilakukan di Sekolah dan Asrama dengan sistem karantina dan memberlakukan aturan yang sama.

Hasil temuan yang diperoleh dari penelitian adalah jika para siswa melakukan pembelajaran jarak jauh, (1) siswa belum sepenuhnya mampu memahami isi materi yang telah dipaparkan lewat media online oleh guru, (2) jaringan internet yang terkadang terganggu di tempat tinggal santri, (3) kurang menguasai penggunaan media pembelajaran secara online sehingga beberapa materi pelajaran yang membutuhkan laboratorium, alat praga dan/atau media pembelajaran tertentu yang tidak dapat tersampaikan oleh guru secara maksimal, (4) banyak siswa yang saat online di google meet tidak aktif karena disambi mengerjakan hal lain (tidak terawasi), dan (5) banyaknya keluangan waktu di rumah membuat santri lebih banyak bermain, bukan belajar, dan karena sebagian besar orang tua santri bekerja, maka santri rentan membuka konten internet yang dapat melalaikan.

Untuk menyelesaikan masalah tersebut, pihak sekolah berusaha mengatasi problematika tersebut seperti memberikan teguran pada siswa yang tidak aktif saat google meet atau belum mengumpulkan tugas dengan mengkomunikasikan pada orang tua, mengadakan pelatihan kepada para guru terkait penggunaan media pembelajaran secara online seperti penggunaan google site, google form, bookwidgets, membuat video pembelajaran menggunakan Canva atau YouTube. Selain itu, sarana dan prasarana pendukung yang digunakan oleh guru dalam proses pembelajaran seperti penguatan jaringan internet sudah dibangun sehingga ketika para guru dan santri sedang mengakses internet tidak mengalami gangguan.

Saat pembelajaran tatap muka pun belum semua sarana sekolah dapat digunakan secara maksimal. Seperti penggunaan videotron untuk pembelajaran belum dapat digunakan karena belum ada sumber daya manusia yang dapat menggunakannya. Dan efek negatif yang dari pembelajaran tatap muka menggunakan teknologi di sekolah adalah, ada saja santri yang bisa mengakses situs-situs yang bisa membuat perhatian santri dalam belajar teralihkan, seperti game onlien walaupun SICC sudah menggunakan aplikasi proteksi.

4. Hasil

Berdasarkan hasil wawancara dan observasi, output dari manajemen digitalisasi 
kurikulum di SICC adalah dengan melihat nilai mata pelajaran TIK (Teknologi Informasi dan Komunikasi) para siswa, namun saat peneliti melakukan penelitian, belum ada Nilai Semester karena mata pelajaran ini baru ada di semester baru 2021, maka indikasi keberhasilan dari manajemen digitalisasi kurikulum di SICC dilihat dari peningkatan digital literasi di kalangan siswa, guru dan pegawai kependidikan lainnya. Salah satu kegiatan digital literasi yang diselenggarakan oleh sekolah bagi siswa adalah lomba membuat konten dakwah bagi para siswa yang diadakan sebulan sekali. Pemenang lomba konten dakwah, hasilnya akan dipajang di majalah dinding sekolah dan mendapat penghargaan dari sekolah. Sekolah pun mengadakan pelatihan bertema digital literasi dua bulan sekali bagi internal dan masyarakat umum.

Selain mengajak para siswa aktif mengikuti kegiatan literasi digital internal di sekolah, sekolah juga memotivasi para siswa untuk mengikuti berbagai lomba literasi digital yang diadakan oleh sekolah dan lembaga lain. Contohnya seperti lomba TIK tingkat SMP, lomba fotografi, lomba menulis ilmiah, lomba sains nasional, dan sebagainya. Hal ini termasuk ke dalam misi tahunan sekolah, yaitu memperoleh minimal 20 piagam penghargaan dalam setahun.

\section{Faktor Pendorong dan Penghambat}

Unsur pendukung meningkatkan mutu pendidikan bisa muncul dari internal maupun dari unsur ekternal. Kedua-duanya menjadi bagian yang penting untuk dilihat, karena kedua-duanya sangat dibutuhkan. Daya dukung yang bersumber dari pihak internal adalah muncul dari dalam institusi, seperti komitmen bersama dari seluruh sivitas akademika, mulai dari kepala sekolah, wakil kepala sekolah, staf, pembina, pelatih, guru, tata laksana sampai komite sekolah untuk melakukan peningkatan mutu pendidikan. Sedangkan daya dukung dari luar adalah dari unsur-unsur ekternal yang peduli terhadap sekolah: masyarakat/orangtua, lingkungan, pemerintah, maupun organisasi kemasyarakatan, dan dunia usaha industri. Adapun menurut (Tanjung, 2021) bahwa faktor penghambat dalam peningkatan mutu sebuah lembaga pendidikan adalah jumlah tenaga kependidikan yang masih terbatas dan sarana prasarana yang belum memadai, serta keterbatasan ekonomi, berdasarkan hasil wawancara dan observasi, didapatkan faktor pendorong dan penghambat manajemen digitalisasi kurikulum di SICC adalah sebagai berikut:

a) Pertama, keterbukaan semua pihak terhadap perubahan berupa digitalisasi administrasi kurikulum,

b) Kedua, komitmen bersama antar setiap unsur-unsur (kepala sekolah, pihak kurikulum, pihak IT, guru, santri, dan orang tua santri) yang terlibat dalam proses pendidikan dengan menjalankan tugas masing-masing.

c) Ketiga, tingkat ekonomi santri yang termasuk golongan menengah ke atas mempermudah proses transformasi digitalisasi administrasi kurikulum, karena orang tua santri mampu mensupport para santri dengan memfasilitasi santri berupa laptop.

d) Keempat, sarana dan prasarana yang disediakan oleh sekolah, seperti internet, gedung laboratorium, ruangan LDC (learning development center) untuk penyimpanan komputer dan seua alat-alat pendukung, ruangan IT (untuk mengawasi CCTV) dan tempat server.

e) Kelima, posisi sekolah yang strategis di tengah kota memberikan dampak positif, yaitu jaringan yang cukup stabil.

f) Keenam, kepemimpinan juga berpengaruh dalam penentuan rencana strategis SICC untuk menjadi sekolah percontohan dalam bidang sains (mencapai banyak prestasi, seperti di olimpiade) dan dalam bidang teknologi (percontohan digital school).

\section{SIMPULAN DAN SARAN}

\section{A. Simpulan}

Program manajemen digitalisasi kurikulum SMP Islam Cendekia Cianjur pada umumnya sudah berjalan dan mampu menjawab kebutuhan era digital saat ini, juga sesuai dengan visi misi SMP Islam Cendekia Cianjur yaitu unggul dan terdepan. Secara khusus terdapat empat kesimpulan terkait Program manajemen digitalisasi kurikulum SMP Islam Cendekia Cianjur, sebagai berikut:

1. Perencanaan program manajemen transformasi digital administrasi kurikulum SMP Islam Cendekia Cianjur dilakukan dengan mengidentifikasi Profil lulusan berdasarkan visi, misi dan tujuan. Dalam satuan kurikulum dimuat mata pelajaran 
Teknologi Informasi dan Komunikasi (TIK) sebagai ciri khas sekolah berbasis teknologi digital serta pemilihan sarana digital sebagai penunjang keberlangsungan pembelajaran. Selain sarana, yang menjadi fokus dalam perencanaan transformasi digital adalah pelatihan sumber daya manusia (SDM) baik oleh internal SMP Islam Cendekia Cianjur maupun bekerjasama dengan pihak eksternal.

2. Pelaksanaan program manajemen transformasi digital administrasi kurikulum SMP Islam Cendekia Cianjur menggunakan berbagai sarana dan flatform digital dari mulai alat tulis digital (pan pad) sarana laptop, infocus, Whatsup group, LMS, hingga media pembelajaran yang dibuat langsung oleh para guru di SMP Islam Cendekia Cianjur yang diantaranya adalah video pembelajaran, modul digital. Sarana evaluasi pembelajaran menggunakan flatform digital secara variatif yang diantaranya adalah Quiziz, Book widgets, google form, google doc dan lainnya.

3. Evaluasi program manajemen transformasi digital administrasi kurikulum SMP Islam Cendekia Cianjur dilakukan dengan cara beragam yaitu dibentuknya tim supervisi oleh kepala sekolah dengan pola kerja secara periodik yaitu satu kali dalam satu bulan, selain supervisi adalah kuisioner berupa angket kepuasan siswa yang diberikan setiap bulan, serta diberikannya angket kepada orangtua siswa disetiap akhir semester sebagai bahan evaluasi dan untuk di tindak lanjuti pada periode berikutnya.

4. Hasil dari manajemen digitalisasi kurikulum di SICC dilihat dari peningkatan kegiatan digital literasi oleh semua pihak di sekolah, terutama para siswa.

5. Faktor-faktor berkaitan dengan program manajemen transformasi digital administrasi kurikulum SMP Islam Cendekia Cianjur dibagi menjadi dua, yaitu faktor pendukung diantaranya: Keterbukaan setiap personil terhadap perubahan, Komitmen bersama dari civitas SICC, Tingkat ekonomi santri yang mayoritas kelas menengah keatas, sarana dan prasarana yang dimiliki lembaga, serta kepemimpinan yang visioner, serta posisi sekolah yang strategis yang memberikan dampak positif terhadap stabilitas jaringan. Sedangkan faktor penghambat adalah jaringan internet yang terkadang kurang stabil, kurangnya kemampuan lembaga dalam memproteksi siswa saat penggunaan internet, perbedaan kecepatan sumber daya manusia dalam penyesuaian dengan kemajuan teknologi, serta Kurangnya regulasi santri untuk mengakses internet saat jam pelajaran berlangsung.

\section{B. Saran}

Berdasarkan hasil penelitian dan kesimpulan penulis menyarankan transformasi digital administrasi kurikulum SMP Islam Cendekia Cianjur penulis menyarankan:

1. Khususnya untuk SICC sendiri disarankan untuk tetap melaksanakan evaluasi secara berkala, meningkatkan kemampuan SDM dalam megoperasikan maupun merancang platform digital sesuai kebutuhan masakini, terus berinovasi dalam rangka mengupgrade kualitas dan fungsi perangkat digital, membuat regulasi untuk keberlangsungan penggunaan perangkat digital.

2. Untuk praktisi pendidikan dan masyarakat diharapkan penelitian ini dapat menjadi salahsatu rujukan dalam mewujudkan Digital School.

3. Untuk peneliti selanjutnya diharapkan melakukan penelitian lebih lanjut untuk melihat variabel lainnya yang mungkin mempengaruhi program manajemen digitalisasi kurikulum.

\section{DAFTAR RUJUKAN}

Arifudin, O. (2019). Manajemen Sistem Penjaminan Mutu Internal (SPMI) Sebagai Upaya Meningkatkan Mutu Perguruan Tinggi. MEA (Manajemen, Ekonomi, \& Akuntansi), 3(1), 161-169.

Arifudin, 0. (2021). Implementasi Balanced Scorecard dalam Mewujudkan Pendidikan Tinggi World Class. Edumaspul: Jurnal Pendidikan, 5(2), 767-775.

Bahri, A. S. (2021). Pengantar Penelitian Pendidikan (Sebuah Tinjauan Teori dan Praktis). Bandung : Widina Bhakti Persada.

Hamalik, O. (2010). Proses Belajar Mengajar. Jakarta: PT Bumi Aksara.

Hanafiah. (2021). Pelatihan Software Mendeley Dalam Peningkatan Kualitas Artikel Ilmiah 
Bagi Mahasiswa. Jurnal Karya Abdi Masyarakat, 5(2), 213-220.

Hasbi, I. (2021). Administrasi Pendidikan (Tinjauan Teori Dan Praktik). Bandung: Widina Bhakti Persada.

Irwansyah, R. (2021). Perkembangan Peserta Didik. Bandung : Widina Bhakti Persada.

Kadir. (2003). Pengembangan E-Learning. Bandung: Universitas Pendidikan Indonesia.

Lopez. (2013). The Influence of the Use of Technology on Students Outcomes in a Blended Learning Context. Journal of Education Tech Research Dev, 61(5), 625638.

Machali. (2015). The Handbook of Education Management: Teori dan Praktik Pengelolaan Sekolah/Madrasah di Indonesia. Jakarta: Kencana.

Mayasari, A., Supriani, Y., \& Arifudin, O. (2021). Implementasi Sistem Informasi Manajemen Akademik Berbasis Teknologi Informasi dalam Meningkatkan Mutu Pelayanan Pembelajaran di SMK. JIIP - Jurnal Ilmiah Ilmu Pendidikan, 4(5), 340-345. https://doi.org/10.54371/jiip.v4i5.277.

Mukniah. (2018). Curriculum Management To Optimize Islamic Studies Course At Public Universities. Tadris, 13(2), 1-11.
Munir. (2008). Pembelajaran Jarak Jauh Berbasis Teknologi Informasi Dan Komunikasi. Bandung: Alfabeta.

Nasser, A. A. (2021). Sistem Penerimaan Siswa Baru Berbasis Web Dalam Meningkatkan Mutu Siswa Di Era Pandemi. Biormatika: Jurnal Ilmiah Fakultas Keguruan Dan Ilmu Pendidikan, 7(1), 100-109.

Rahayu, Y. N. (2020). Program Linier (Teori Dan Aplikasi). Bandung : Widina Bhakti Persada.

Rezky. (2020). Problematika Pembelajaran Bahasa Indonesia Berbasis Teks. Jurnal Pembelajaran Bahasa Dan Sastra Indonesia, 1(1), 40-47.

Smaldino. (2014). Intructional Technology \& Media For Learning (Teknologi Pembelajaran Dan Media Untuk Belajar). Jakarta: Kencana Prenada Media Group.

Sugiyono. (2015). Metode Penelitian Pendidikan (Pendekatan Kuantitatif,. Kualitatif dan $R \& D)$. Bandung : CV. Alfabeta.

Tanjung, R., Hanafiah, H., Arifudin, O., \& Mulyadi, D. (2021). Kompetensi Manajerial Kepala Sekolah Dalam Meningkatkan Kinerja Guru Sekolah Dasar. JIIP - Jurnal Ilmiah Ilmu Pendidikan, 4(4), 291-296. https://doi.org/10.54371/iiip.v4i4.272. 